\title{
Blusukan and Personal Branding of Regional Head Election Candidates in Solo City
}

\author{
Betty Gama ${ }^{1}$, Bani Sudardi' ${ }^{2}$, Wakit Abdullah ${ }^{3}$, Mahendra Wijaya ${ }^{4}$ \\ \{bettygama_62@ymail.com ${ }^{1}$, banisudardi@yahoo.co.id ${ }^{2}$, abdullahwakit@yahoo.com ${ }^{3}$ \} \\ ${ }^{1}$ Candidate Doctor of Cultural Studies at Sebelas Maret University, Surakarta, Indonesia \\ ${ }^{1}$ Lecturer of Veteran University Bangun Nusantara Sukoharjo, Indonesia \\ ${ }^{2,3,4}$ Sebelas Maret University Surakarta, Indonesia
}

\begin{abstract}
Blusukan is one of the campaign methods that can influence voters' voices. Interpersonal communication built between candidates and the community can lead to positive personal branding. Therefore the regional head election campaign to elect Solo mayor and deputy mayor through blusukan was very effective in influencing potential voters. The purpose of this study is to find out how the process of forming personal branding through blusukan and to find out the interaction patterns that are built in it carried out by FX Hadi Rudyatmo pairs. This research uses a qualitative descriptive research method. The object of research is the candidates for the Solo City Election in 2015-2020, especially on FX. Hadi Rudyatmo. The candidate's FX. Hadi Rudyatmo was chosen as the object of the study because during his candidacy for mayor or deputy mayor, three consecutive periods were chosen. The results of the research shows, the campaign was blusukan carried out by FX candidates. Hadi Rudyatmo uses the approach Seven Si (communication, coordination, solutions, socialization, realization, correction and evaluation), while the interaction pattern is built when blusukan using Javanese cultural identity, namely language and clothing.
\end{abstract}

Keywords: blusukan, candidates, elections

\section{Introduction}

Regional Head Election in Indonesia has been going on for three times, namely in 2005, 2010 and 2015. During that blusukan as political communication strategies for winning the election campaign proved able to attract the attention of potential voters or prospective voter. In political communication, audiences are a large number of people who receive political messages conveyed through the media, such as the mass media, new media, and social media. In Regional Head Election, political audiences who are seen as recipients of messages are voters. Voters are all parties who are the main goal of political candidates to be influenced and convinced to support and give their voting rights [1]. Whereas political campaigns are an effort to increase the popularity and electability of political actors. Therefore the campaign is a conscious effort of the candidates to build harmonious relationships and mutual needs with the public. One of the efforts to get the most votes in the Regional Head Election campaign is to do blusukan. Blusukan began to be known to the people of Surakarta City in 2005 when Joko Widodo (Jokowi) with his partner FX Hadi Rudyatmo won the election of Mayor and Deputy Mayor of Surakarta for the period 2005-2010. Blusukan that was carried out was also inseparable from the use of Javanese cultural identity, such as the use of clothing in the form of lurik (Javanese clothing), batik clothes, blangkon (hats), language and andhap asor (respect). [2] 
The successful implementation of the Solo Regional Election in 2010 was measured by three types of parameters, first, successful electoral administration, namely the electoral process can be carried out on time according to the schedule and stages. Second, electoral political success, namely elections can take place democratically supported by the independence and legitimacy of the organizers and the low level of horizontal conflict. Third, the success of the quality of its products, namely elections can produce good and quality candidate pairs by community expectations. The success achieved is a form of good cooperation from various parties including among the candidates for mayors and deputy mayors.

Regional Head Election is the election of candidates for mayors and prospective deputy mayors of the city of Solo which are held every five years. If further noted, there is a candidate who won the Solo City Election as much as three times in a row, namely FX. Hadi Rudyatmo (currently serving as Mayor of Solo). In 2005, the partner of Joko Widodo-FX. Hadi Rudyatmo won the regional election with a vote of 99,961 votes $(36.6 \%)$. In 2010 , the pair Joko Widodo-FX. Hadi Rudyatmo ran again and managed to get 248,243 votes (90.09\%). 2015 FX pairs. Hadi Rudyatmo-Achmad Purnomo managed to obtain 169,902 votes (60.39\%). The success of Hadi Rudyatmo winning the Regional Head Election campaign three times in a row is an extraordinary achievement and this is inseparable from the efforts made, among others by committing blusukan in various areas in Solo City. The success of Hadi Rudyatmo in packing the right content makes the blusukan done in the community. Blusukan can increase personal branding Hadi Rudyatmo's as a candidate for mayor. A brand that is inherent in someone is called personal branding. Personal branding aims to build audience associations and expectations of a person. According to Timothy $\mathrm{P} \mathrm{O}^{\prime}$ Brien [3], personal branding is a personal identity about the quality and value possessed by someone who can create an emotional response to others. Personal branding is an illustration of a person's ability, superiority and reputation, which can show someone's privileges and excellence in a particular field.

The term blusukan has been known since the days of the Javanese Kings. The Javanese king carried out blusukan namely Pakoeboewono V, Pangeran Sambernyoro or Mangkunegoro I and Sri Sultan Hamengkubuwono IX from Yogyakarta. After Indonesia's independence, blusukan was carried out by Indonesian officials, such as President Soekarno, President Soeharto, President Susilo Bambang Yudoyono and Joko Widodo. Although Blusukan has been known since ancient times but the term blusukan became popular when Joko Widodo became mayor of the city of Solo in 2005-2010 and increasingly popular when Joko Widodo became the Governor of DKI and then elected President of the Republic of Indonesia to date (2012-2019). The term blusukan refers to the behavior of wandering in there into here, just to recognize a situation and condition of a place naturally or culturally. Blusukan is a term used by people to travel to places with problems that have not been revealed.

The word blusukan comes from the Javanese language, namely "bloesoek" or "blusuk." The word is then given the ending "-an" to "bloesoekan" or "blusukan" which means " mlebu ing ngendi-endi " or go everywhere (Poerwadarminta, 1939 ). Literally, the term blusukan can be defined as the activity of someone entering foreign places. If it is associated with a political context, blusukan has three terms, namely: 1. The visit to the general candidates (which usually is) slums as a campaign strategy of door-to-door,2. The visit to a specific location previously scheduled on capacity as a leader (presidential visits); 3. The activity of visiting leaders to directly review the problems that exist in the community [4] 
Charles U Larson in Ruslan [5] divides the campaign in several types. first, productoriented campaign, which is a product-oriented and commercial campaign. Second, candidateoriented campaigns are campaigns that are oriented towards candidates for the sake of political campaigns, where campaigners try to gain as much support as possible through political campaigns. Third, ideological or cause-oriented campaigns are campaigns that are more specific and have dimensions of social change ... in this case; the authors discuss the second type of campaign, namely candidate-oriented campaigns.

To improve the candidate's self-image, various communication strategies are carried out to build a positive image in the eyes of prospective voters. All candidates try to build a positive image by utilizing various media both mass communication and interpersonal communication so that they can be accepted in the community. This study analyzes interpersonal communication carried out by FX candidates. Hadi Rudyatmo in conducting a regional head election campaign in the city of Solo. Together with his partner, he was elected mayor of Solo City for three consecutive periods, a remarkable achievement. How the efforts made to attract the attention of the mass campaign is nothing but doing blusukan. Therefore the purpose of this study is to find out how the process of forming personal branding through blusukan and to know the patterns of interaction that are built-in by the pair of Joko WidodoFX. Hadi Rudyatmo.

\section{Methodology}

This study uses qualitative methods, because it only describes situations or events and is not intended to find or explain relationships and not test hypotheses or make predictions [6]]. This research is also descriptive in that it describes or portray the state of the object of research based on the facts that are evident [7] The research object is a candidate local elections (elections) Solo mainly blusukan performed by FX. Hadi Rudyatmo and his partner. FX. Hadi Rudyatmo was chosen because he succeeded in winning the Regional Head Election three times in a row. The Data collection techniques using interviews, literature, and documentation. Methods of data analysis using triangulation of sources and data.

\section{Results and Discussion}

FX. Hadi Rudyatmo before serving as mayor of Solo held the position of Chair of the Democratic Party of Struggle or PDI-P (in the present 2000). In 2005 the pair Joko Widodo FX. Hadi Rudyatmo nominated himself as mayor and deputy mayor. The activity blusukan has been done by FX. Hadi Rudyatmo when he served as Chair of PDI-P. So when Hadi Rudyatmo nominated himself as a candidate for the elections, many Solo people knew him. Even so, the campaign period was really utilized by Joko Widodo - FX. Hadi Rudyatmo in 2005 to attract the attention of the masses by committing blusukan to various regions. Campaigns are an important factor in local elections because the aim of the campaign is as socialization so that candidates can be recognized by the community. Therefore blusukan as a form of the campaign needs to be done in order to get to know the community more closely and win the competition.

\subsection{Blusukan Approach by Election Candidates}

Although technology is progressing but the power of blusukan is an extraordinary power. The strategy blusukan that is carried out in a real way also shows the existence of interpersonal communication patterns that are close between the candidates and the 
community without any obstacles. If a disturbance occurs, the interference is not too meaningful because it will be overcome immediately. Interpersonal communication is carried out not without reason, but communication that is full of symbolic meaning. Clothing, speech, posture and other attributes used by candidates determine people's perceptions of the candidate. Blusukan is one of the political forces to win general elections or regional head elections, as was done by the Jokowi-Rudy pair.

The campaign period is a time when regional election candidates introduce themselves to the community by doing various ways, both through interpersonal communication and mass communication. Campaign Blusukan is a form of interpersonal communication. Based on interviews conducted between researchers with FX. Hadi Rudyatmo in his office on April 30, 2019, blusukan conducted using the approach Seven Si. Seven Si is an approach that is often done by Rudy when he was PDI-P Chair and it turned out that this approach was very effective during the 2005 regional head election campaign. The approach Seven Si was the main keyword in getting to know the community consisting of communication, coordination, solutions, socialization, realization, correction and evaluation.

Blusukan is done by communicating with the community, hearing complaints and trying to solve the problems faced by the community. Rudy then coordinated with related parties about what was expected by the community. All the problems can then be sought for the best solution and then returned to the community during the election campaign. So when the Jokowi-Rudy pair did the blusukan, the pair had known the problems they faced and lived up to conveying the solution to the problem. The findings blusukan by Rudy Jokowi-made program of work then socialized during the campaign. The socialization was conveyed to the community in the hope that if elected as the mayor and vice mayor pair, the socialization of the work program would be realized. Even though all the promises at the time of the campaign have been realized, the corrections are still carried out in the implementation to determine the extent of the success of the program and at the same time carry out evaluations. The approach is Seven $\mathrm{Si}$ very appropriate when the Jokowi-Rudy couple relocates some traditional markets and street vendors in Solo.

For FX. Hadi Rudyatmo, who currently serves as mayor of Solo City (2015-2020), works as a public servant and is not the person served, related to the Blusukan campaign, Rudy said, " No need to spend a lot of funds for the campaign. To be chosen we must be known to the public. Don't when you need us to blusukan when you don't need us to sit at home ". Personal branding is done by the couple Joko Widodo - FX. Hadi Rudyatmo through a campaign blusukan. The successful blusukan is not because of the work program received by the public but also the personal identity of this pair is considered the community as someone who is polite, courteous and has a soul as a leader. In Political Public Relations, Baines defines political public relations as a way of building mutually beneficial relationships to achieve political goals with public key stakeholders, namely voters and secondary consisting of campaign staff, competitors, friends, including the media [8]

\subsection{The Symbol of Javanese Culture in Blusukan Campaigns}

A study says that symbolic politics or symbolic politics was born from research. Neuroscience [9]. The results of the study concluded that a person is motivated to take an action due to emotional factors and not based on rational calculations. Based on these findings, political actors use certain symbols as a strategy to achieve certain political goals.

The use of political symbols is also found in FX Hadi Rudyatmo partner campaigns in the form of clothing and language. Clothing is a sign of identity. Clothing is a mirror of identity, status, gender, having symbolic value Clothing also reflects power relations and 
differences in social, political and religious views. Consistency of Joko Widodo - FX. Hadi Rudyatmo in matters of dress and campaigning made the lurik and batik clothes during blusukan as political symbols during the campaign for the election of candidates for mayor and vice mayor of the city of Solo. The batik shirt with the motif godhong kates (papaya leaves) is used by Joko Widodo - FX. Hadi Rudyatmo during the 2010 Election campaign. The outfit was used when Hadi Rudyatmo attended the Submission of Vision and Mission of the Candidate Pair of Mayor and Deputy Mayor [10]. On the news at Solopos with the title JoDy tantang pakai batik godhong kates saat kerja ( Jo-Dy challenged using batik godhong kates at work), among others, the news explained that themotif godhong kates was worn Jokowi was indeed chosen as branding [11]

Besides the use of batik clothing with motifs of godhong kates, FX. Hadi Rudyatmo also uses Javanese identity clothing, lurik clothing. FX. Hadi Rudyatmo - Achmad Purnomo pair uses clothes lurik and caping (typical peasant headgear) when registering as a candidate for Solo City mayor and deputy mayor for the period 2015-2020 [12]. Striated clothes are deliberately used by FX pairs. Hadi Rudyatmo - Achmad Purnomo as a political symbol for the Solo City Election. The basic rule is that something can be called a symbol, first, simple. The use of symbols on political contestation aims to create similarities so that candidates can be easily identified. Second, easy to remember. The symbol requirement is related to the first condition, because of its simplicity, the symbol becomes easy to remember. Third, it is easily mass-produced. Basically, political symbols are part of publication efforts. The lurik clothes used by FX Hadi Rudyatmo - Ahmad and the batik clothes with the godhong kates motif used by Joko Widodo- FX Hadi Rudyatmo are forms of clothing that are easily reproduced in bulk.

Language is a system of symbols that allows people to share meaning. In verbal communication, the language symbol used is verbal language, both oral and written. The language of a nation or tribe comes from interactions and relationships between citizens with each other [13]. The implementation of the Surakarta Regional Head Election campaign was inseparable from the Javanese cultural identity of using the local language, namely Javanese. Javanese is one of the cultural identities that exist in Indonesia. Candidates for mayors and deputy mayors as Javanese (Surakarta) people in conducting campaigns in addition to using Indonesian national language also use regional languages.

Couple Joko Widodo - FX. Hadi Rudyatmo used the Javanese language when asking for support from the community when registering as a candidate for mayor and deputy mayor (Solopos, March 5, 2010) [14][14][14]

"Kula saget. Namung kula nyuwun dukungan sedaya brayan agung Kutha Sala amrih saenipun. Mangke tanggal 26 April 2010, sumangga kita sedaya sareng-sareng rawuh dateng TPS, nyoblos Jokowi-Rudy"

(Meaning, I can. But I ask for support from all Solo people in order to better.

Let us come to the voting place to vote for Jokowi-Rudy on April 26, 2010).

Language as a communication tool will be easy to understand if between communicators and communicants have the same languages. Language is a combination of words arranged systematically, so that they can be used as communication tools. The word itself is an integral part of the symbols used by the community groups. 


\section{Conclusion}

Personal branding is an illustration of the candidates' abilities, advantages and reputation. Positive personal branding can increase the number of potential voters. Buskin made by FX. Hade Rudyatmo pairs with the approach Seven Si made the people visited feel valued and respected. In addition, the Javanese cultural identity used by candidates in the form of clothing and language was also able to attract sympathizers of prospective voters. FX. Hadi Rudyatmo success, both in partnership with Joko Widodo and Achmad Purnomo, made blusukan as one of the campaign methods that could influence public participation.

\section{References}

[1] Firmansyah, "Marketing Politik: Antara Pemahaman dan Realitas." p. 38, 2008.

[2] B Gama, B Sudardi, M Wijaya W Abdullah, "Blusukan Cultural as a Political Power in The Regional Head Election of Surakarta.," in Workshop on Language, Literature and Society for Education. Conference. dates 21st-22nd Dec 2018, 2019.

[3] D. Haroen, "Personal Branding: Kunci Kesuksesan Berkiprah di Dunia Politik," The SAGE Encyclopedia of Quality and the Service Economy. Jalasutra, Jakarta, p. 1, 2014.

[4] S. Anita Fitria, "Perspektif Kritis Pada Praktik Political Public Relations Melalui Symbolic Politic.” Skripsi. FISIP Program Sarjana Regular, Depok, pp. 64-65, 2014.

[5] R. Ruslan, "Management Public Relations dan Media Komunikasi, Konsep dan Aplikasi." PT Raja Grafindo Persada., Jakarta, 2008.

[6] J. Rakhmat, "Metode Penelitian Komunikasi.” Remaja Rosdakarya, Bandung, 2001.

[7] Namawi Martini, "Instrumen Penelitian Bidang Sosial." UGM Press, Yogyakarta, 1992.

[8] S. Stromback, Jesper dan Kiousis, "Political public relations: Principles and applications," Political Public Relations: Principles and Applications. Routledge, New York, p. 115, 2011.

[9] S. J. Kaufman, "Symbolic Politics or Rational Choice? Testing Theories of Extreme Ethnic Violence. Presiden and Fellows of Harvard College And The Massachusetts Institute of Technology." International Security, Vol 30, No.4, Spring, pp. 45-48, 2006.

[10] Solopos, “Antara batik dan falsafah Jawa.” 10 April 2010, Solo, 2010.

[11] Solopos, "Jo-Dy tantang pakai batik godhong kates saat kerja." 20 April 2010, Solo, 2010.

[12] Solopos, "Daftar Pilkada Rudy-Purnomo Kenakan Lurik dan Ngonthel." 26 Juli 2015, Solo, 2015.

[13] A. M. Hardjana, “Komunikasi Intrapersonal dan Interpersonal.” Kanisius, Yogyakarta, p. 22, 2003.

[14] B Gama, B Sudardi, M Wijaya, W Abdullah, “The Use Of Javanese Ethnic Cultural Identity In The Campaign For Local Leader Election In Surakarta. Proceding The 6th International Seminar On Nusantara Heritage. 25th September 2017.” ISI Denp[asar, Bali, p. 92, 2017. 